\title{
Human RAD52 Protein Has Extreme Thermal Stability ${ }^{\dagger}$
}

\author{
Wasantha Ranatunga, Doba Jackson, Robert A. Flowers II, and Gloria E. O. Borgstahl* \\ Department of Chemistry, The University of Toledo, Toledo, Ohio 43606-3390 \\ Received February 2, 2001; Revised Manuscript Received April 27, 2001
}

\begin{abstract}
The human RAD52 protein plays an important role in the earliest stages of chromosomal double-strand break repair via the homologous recombination pathway. Individual subunits of RAD52 associate into seven-membered rings. These rings can form higher order complexes. RAD52 binds to DNA breaks, and recent studies suggest that the higher order self-association of the rings promotes DNA end joining. Monomers of the RAD52(1-192) deletion mutant also associate into ring structures but do not form higher order complexes. The thermal stability of wild-type and mutant RAD52 was studied by differential scanning calorimetry. Three thermal transitions (labeled A, B, and C) were observed with melting temperatures of $38.8,73.1$, and $115.2^{\circ} \mathrm{C}$. The RAD52(1-192) mutant had only two thermal transitions at 47.6 and $100.9{ }^{\circ} \mathrm{C}$ (labeled B and C). Transitions were labeled such that transition C corresponds to complete unfolding of the protein. The effect of temperature and protein concentration on RAD52 self-association was analyzed by dynamic light scattering. From these data a four-state hypothetical model was developed to explain the thermal denaturation profile of wild-type RAD52. The three thermal transitions in this model were assigned as follows. Transition A was attributed to the disruption of higher order assemblies of RAD52 rings, transition B to the disruption of rings to individual subunits, and transition $\mathrm{C}$ to complete unfolding. The ring-shaped quaternary structure of RAD52 and the formation of higher ordered complexes of rings appear to contribute to the extreme stability of RAD52. Higher ordered complexes of rings are stable at physiological temperatures in vitro.
\end{abstract}

RAD52 ${ }^{1}$ protein plays a critical role in mitotic and meiotic recombination as well as double-strand break repair $(1,2)$. On the basis of a series of protein-protein interaction assays and DNA binding studies (3-5), a domain map of human RAD52 (RAD52) was proposed by Park et al. (Figure 1). Electron microscopy (EM) studies of Saccharomyces cerevisiae and human RAD52 have revealed formation of ringshaped structures (9-13 $\mathrm{nm}$ in diameter), as well as higher order aggregates $(6-8)$. The RAD52 rings appear to be composed of seven subunits (9). EM studies also showed that RAD52 recognizes and binds to double-stranded DNA ends as an aggregated complex that ranges in size from approximately 15 to $60 \mathrm{~nm}$ in diameter (8). This binding promoted end-to-end association between DNA molecules and stimulated the ligation of both cohesive and blunt DNA ends (8). Recently, by studying wild type and two deletion mutants of RAD52 (Figure 1), we demonstrated that the selfassociation domain in the N-terminal half of RAD52 is responsible for ring formation and that elements in the C-terminal half of the molecule participate in the formation of higher order complexes of rings (10).

$\dagger$ This work was supported by the U.S. Army Medical Research and Material Command under DAMD17-98-1-8251 (G.E.O.B.), DAMD1700-1-0469 (W.R.), and DAMD17-00-1-0467 (D.J.).

* To whom correspondence should be addressed. Telephone: 419530-1501. Fax: 419-530-4033. E-mail: gborgst@uoft02.utoledo.edu.

${ }^{1}$ Abbreviations: RAD52, human RAD52; DLS, dynamic light scattering; DSC, differential scanning calorimetry; EM, electron microscopy; MnSOD, manganese superoxide dismutase; SOS, sum of squares; $R_{\mathrm{H}}$, hydrodynamic radius; $T_{\mathrm{M}}$, melting temperature.
Due to the biological interest of human RAD52 and the apparent biochemical importance of RAD52 self-association in DNA repair, we studied its multiple levels of selfassociation and stability using biophysical methods. The stability of wild-type RAD52 was studied by differential scanning calorimetry (DSC). To investigate the basis for the extreme stability of RAD52 that was discovered, two mutants were also studied, RAD52(1-192) and RAD52(218-418) (Figure 1). The effects of temperature and protein concentration on the hydrodynamic radius $\left(R_{\mathrm{H}}\right)$ of RAD52 were studied by dynamic light scattering (DLS). Finally, a hypothetical model of the effects of protein aggregation state on thermal stability was developed.

\section{MATERIALS AND METHODS}

Protein Purification. The domain structures for wild-type RAD52, RAD52(1-192), and RAD52(218-418) are described in Figure 1. Proteins were expressed, purified under reducing conditions, and concentrated as described (10). Unfortunately, enterokinase cleavage was nonspecific, and the histidine-patch thioredoxin (Invitrogen) could not be separated from the 218-418 peptide (Jackson, unpublished results). After the extreme thermal stability of wild-type RAD52 was observed, subsequent purifications included a heat treatment step. The lysate was heated to $55{ }^{\circ} \mathrm{C}$ for 30 min prior to the chromatography steps. Samples were concentrated using an Ultrafree-15 centrifugal filter device. After each step of concentration, the samples were analyzed by DLS. Protein concentrations were determined using the Bradford assay (Bio-Rad) with bovine serum albumin as a standard. 


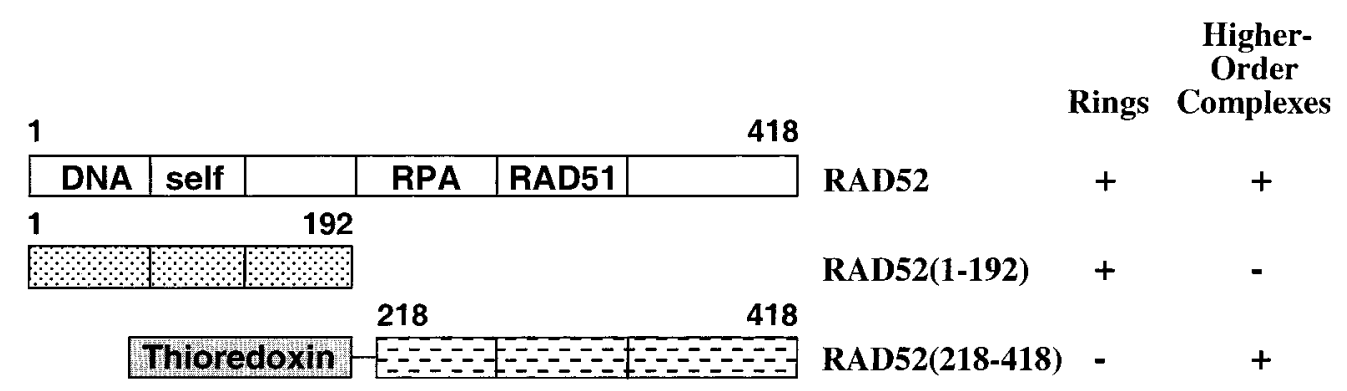

FIGURE 1: Wild-type RAD52 and deletion mutants. Beginning and ending residue numbers of each mutant are indicated along with domain structure. The following domains and residue numbers were defined by Park et al. (16): DNA binding (39-80), self-association (85-159), RPA binding (221-280), and RAD51 binding (290-330). The structural characterization of wild-type and mutant RAD52 by Ranatunga et al. is summarized on the right (10). Wild-type RAD52 and RAD51(1-192) have six histidines fused to the C-terminus. For the RAD52(218-418) mutant, a thrombin-cleavable six-histidine tag is fused to the N-terminus of the histidine-patch thioredoxin, and an enterokinase cleavage site separates histidine-patch thioredoxin from RAD52(218-418).

Differential Scanning Calorimetry. Protein and reference solutions were degassed under a vacuum for 15 min before data acquisition. The concentration of wild-type RAD52 was 2.0 and $3.5 \mathrm{mg} / \mathrm{mL}$, RAD52(1-192) was $7.2 \mathrm{mg} / \mathrm{mL}$, and RAD52(218-418) was $3.1 \mathrm{mg} / \mathrm{mL}$. The wild-type RAD52 sample was concentrated to $11.5 \mathrm{mg} / \mathrm{mL}$ before dilution to either 2.0 or $3.5 \mathrm{mg} / \mathrm{mL}$. The concentrations of wild-type RAD52 and RAD52(218-418) were limited by the quantity of protein available. The protein samples and reference solutions were loaded into their respective cells in the MicroCal MC-2 differential scanning calorimeter. An external pressure of 30 psi was applied with nitrogen gas to both sample and reference cells. The sample was scanned relative to the reference solution over a temperature range of $5-120{ }^{\circ} \mathrm{C}$ at a rate of $45^{\circ} \mathrm{C} / \mathrm{h}$. DSC measurements on buffer alone had no transitions for the temperature range $5-120^{\circ} \mathrm{C}$. The baseline and change in specific heat $\left(\Delta C_{p}\right)$ upon denaturation were corrected according to standard techniques (11). DSC data were fit to a two- or three-state model using the Origin DSC software provided by Microcal Inc.

Dynamic Light Scattering Analysis. DLS was carried out using a DynaPro-801 molecular sizing instrument equipped with a temperature-controlled microsampler (Protein Solutions). A $50 \mu \mathrm{L}$ sample was passed through a filtering assembly equipped with a $100 \mathrm{~nm}$ filter into a $12 \mu \mathrm{L}$ chamber quartz cuvette. For each experiment, 35-60 measurements were taken. The data were first analyzed using Dynamics 4.0 software and then with DynaLS software. The refractive index and viscosity of the buffer at each temperature were measured and the proper corrections applied to the data. Baseline and sum of squares (SOS) error values were reported by Dynamics 4.0. The baseline is the measured value of the last coefficient in the correlation curve. Baselines within the range from 0.977 to 1.002 were interpreted as monomodal, and those greater than 1.002 were bi- or multimodal. The SOS error is the sum of squares difference between the measured correlation curve and the best-fit curve. SOS errors less than 5.000 were considered negligible. Errors between 5.000 and 20.000 were considered as low and probably due to low protein concentration or a small amount of polydispersity. Errors greater than 20.000 were considered as high and are probably due to high polydispersity in size distribution (aggregation) or irregular solvent. Mean $R_{\mathrm{H}}$, standard deviation, and percent of peak area are reported from DynaLS using the optimized resolution. Due to the irregular solvent, the SOS errors increased for diluted samples, and it was necessary to use DynaLS to separate the solvent peak from the protein peak.

\section{RESULTS AND DISCUSSION}

Differential Scanning Calorimetry. Thermal stability profiles of wild-type RAD52, RAD52(1-192), and RAD52(218-418) were obtained by DSC (Figure 2 and Table 1). For wild-type RAD52 and RAD52(1-192) the DSC transitions were labeled $\mathrm{A}, \mathrm{B}$, or $\mathrm{C}$ such that total unfolding was always labeled C. For wild-type RAD52, at $2.0 \mathrm{mg} / \mathrm{mL}$, the DSC profile was composed of two transitions (labeled B and C) with melting temperatures $\left(T_{\mathrm{M}}\right)$ of 78.3 and $101.6{ }^{\circ} \mathrm{C}$ (Table 1). At $3.5 \mathrm{mg} / \mathrm{mL}$, the wild-type RAD52 DSC profile was composed of three distinct transitions (labeled $\mathrm{A}, \mathrm{B}$, and $\mathrm{C}$ in Figure 2A) with $T_{\mathrm{M}}$ 's of $38.8,73.1$, and $115.2{ }^{\circ} \mathrm{C}$ (Table $1)$. When the concentration of wild-type RAD52 was increased, transition $\mathrm{C}$ was shifted to a higher temperature by $13{ }^{\circ} \mathrm{C}$. Transition A could be measured only if the sample was first concentrated to $11.5 \mathrm{mg} / \mathrm{mL}$ and then diluted to $3.5 \mathrm{mg} / \mathrm{mL}$. For RAD52(1-192) two transitions were observed at 47.6 and $100.9{ }^{\circ} \mathrm{C}$ (labeled B and C in Figure 2B). The deletion of the $\mathrm{C}$-terminal half of RAD52 decreased the $T_{\mathrm{M}}$ of transitions $\mathrm{B}$ and $\mathrm{C}$ by 25 and $14{ }^{\circ} \mathrm{C}$, respectively.

Our earlier analysis demonstrated that wild-type RAD52 forms ring structures as well as higher order complexes of rings but RAD52(1-192) forms rings but not the aggregates of rings (10). The size of the wild-type RAD52 higher order complexes, as well as the proportion of the rings in a higher order complex, is dependent on concentration. RAD52(1192) rings do not form higher ordered complexes, at any concentration. DSC transition A was dependent on the concentration of wild-type RAD52 and was not observed for RAD52(1-192). Therefore, it appeared that transition A corresponded to the thermal disruption of aggregates to form single rings in solution, transition $\mathrm{B}$ to the break up of rings to monomers, and transition $\mathrm{C}$ to the total unfolding of monomers.

The DSC profile of RAD52(218-418) is also consistent with this interpretation (Figure 2C). RAD52(218-418) forms a complex of two to four monomers depending on the concentration but does not form ring structures in solution (10). It has a relatively low $T_{\mathrm{M}}$ of $53-59{ }^{\circ} \mathrm{C}$, and it appears that the C-terminal half of RAD52, which cannot form rings, is not as thermally stable as the ring-structured $\mathrm{N}$-terminal half.

Wild-type Escherichia coli thioredoxin is a very stable protein with a $T_{\mathrm{M}}$ of $\sim 85^{\circ} \mathrm{C}$ for the oxidized form and $\sim 73$ 

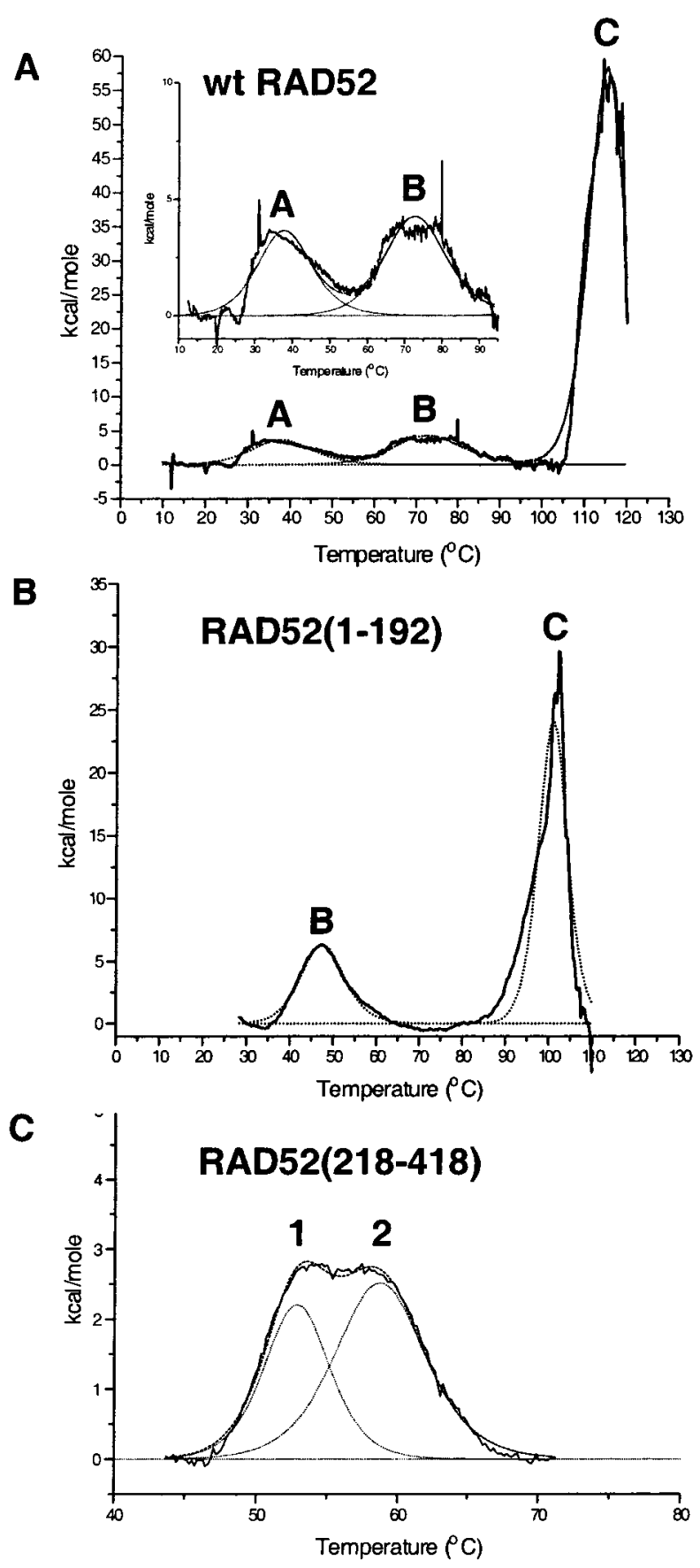

FIgURE 2: Thermal stability of wild-type RAD52 and deletion mutants. DSC profiles for (A) wild-type RAD52 were analyzed at $0.038 \mathrm{mM}(3.5 \mathrm{mg} / \mathrm{mL})$, (B) RAD52 $(1-192)$ at $0.325 \mathrm{mM}(7.2$ $\mathrm{mg} / \mathrm{mL})$, and (C) RAD52(218-418) at $0.082 \mathrm{mM}(3.1 \mathrm{mg} / \mathrm{mL})$. For RAD52(218-418) there were no transitions above $70^{\circ} \mathrm{C}$.

${ }^{\circ} \mathrm{C}$ for the reduced form $(12,13)$. When thioredoxin is fused to other proteins, it can improve their solubility and, especially when in the oxidized form, improve their thermal stability, allowing a heat step during purification. Histidinepatch thioredoxin in the reduced state was expected to have a $T_{\mathrm{M}}$ of $\sim 67^{\circ} \mathrm{C}(12-14)$. We were unable to specifically cleave thioredoxin from RAD52(218-418) with enterokinase, so the exact contributions of thioredoxin and RAD52(218-418) to the DSC profile of the fusion protein could not be determined. It is apparent that fusing thioredoxin to RAD52(218-418) has reduced the $T_{\mathrm{M}}$ of thioredoxin significantly and that RAD52(218-418) by itself would prob-
Table 1: Thermodynamic Parameters from DSC Measurement of RAD52 Proteins

\begin{tabular}{lccr}
\hline \multicolumn{1}{c}{ protein } & concn $(\mathrm{mg} / \mathrm{mL})$ & component & $T_{\mathrm{M}}\left({ }^{\circ} \mathrm{C}\right)$ \\
\hline RAD52 $^{a}$ & 2.0 & $\mathrm{~B}$ & 78.3 \\
& & $\mathrm{C}$ & 101.6 \\
RAD52 $^{b}$ & 3.5 & $\mathrm{~A}$ & 38.8 \\
& & $\mathrm{~B}$ & 73.1 \\
RAD52(1-192) $^{c}$ & 7.2 & $\mathrm{C}$ & 115.2 \\
& & $\mathrm{~B}$ & 47.6 \\
RAD52(218-418) $^{d}$ & 3.1 & $\mathrm{C}$ & 100.9 \\
& & 1 & 53.4 \\
& & 2 & 59.1 \\
\hline
\end{tabular}

${ }^{a}$ This sample was concentrated to $11.5 \mathrm{mg} / \mathrm{mL}$ and then diluted to $2.0 \mathrm{mg} / \mathrm{mL}$ (similar to Table 2, line 12) and does not contain higher ordered assemblies of rings. ${ }^{b}$ This sample was concentrated to 11.5 $\mathrm{mg} / \mathrm{mL}$ and then diluted to $3.5 \mathrm{mg} / \mathrm{mL}$ for DSC measurements (similar to Table 2, line 7, and Figure 3E) and contains higher ordered complexes of rings. ${ }^{c}$ RAD52(1-192) forms rings but does not form higher ordered assemblies of rings (10). ${ }^{d}$ RAD52(218-418) does not form rings but does self-associate $(10)$.

ably have a $T_{\mathrm{M}}$ lower than that measured for the fusion protein.

The reversibility of transitions A, B, and C for wild-type RAD52 was studied by DSC, using an $11.5 \mathrm{mg} / \mathrm{mL}$ sample diluted to $3.5 \mathrm{mg} / \mathrm{mL}$. Three experiments were performed, and the presence of precipitation was noted after each (data not shown). First, the sample was heated to $55{ }^{\circ} \mathrm{C}$ and then slowly returned to $20{ }^{\circ} \mathrm{C}$ overnight. Transition A was observed, and the protein remained in solution. Then the same sample was heated to $95{ }^{\circ} \mathrm{C}$ and slowly returned to 20 ${ }^{\circ} \mathrm{C}$ overnight. During this second experiment, transition A did not return, possibly due to the protein concentration used (see discussion of DLS data, Table 2, lines 7-9), and transition $\mathrm{B}$ was lowered to $65{ }^{\circ} \mathrm{C}$. After the second experiment there was a slight amount of precipitate, but the majority of the protein was still in solution. For the third experiment, the sample was heated to $120^{\circ} \mathrm{C}$, and there was only one significant peak at $94{ }^{\circ} \mathrm{C}$ and the protein completely precipitated. The $T_{\mathrm{M}}$ for complete unfolding was lower than that measured from fresh sample $\left(115^{\circ} \mathrm{C}\right.$ for peak $\mathrm{C}$, Figure $2 \mathrm{~A}$ ), indicating that the protein did not properly reassemble after the second experiment and that the process of unfolding is irreversible under this set of experimental conditions.

The irreversibility of transition B was also noted in experiments performed during the addition of a heat step to the purification protocol for wild-type RAD52. Lysates were heated in 5 deg increments between 55 and $80^{\circ} \mathrm{C}$, centrifuged, and analyzed by SDS-PAGE. RAD52 began to precipitate after $65^{\circ} \mathrm{C}$ (data not shown). This supports the conclusion that transition $\mathrm{B}$ in the thermal denaturation of RAD52 is irreversible.

Dynamic Light Scattering. The response of RAD52 rings and higher ordered complexes to concentration and temperature was studied by DLS. The upper temperature limit of the DLS microsampler was $50{ }^{\circ} \mathrm{C}$ so theoretically data on transition A of wild-type RAD52 and transition B of RAD52(1-192) could be measured.

The procedure followed for sample preparation affected the detection of DSC transition $\mathrm{A}$ and the $T_{\mathrm{M}}$ value of transition C for wild-type RAD52, so the effects of protein concentration and temperature on the $R_{\mathrm{H}}$ of wild-type RAD52 were studied using DLS. In a series of experiments, the protein concentration was increased from 3.5 to $11.5 \mathrm{mg} /$ 
Table 2: Effect of Temperature and Concentration on $R_{\mathrm{H}}$ of Wild-Type RAD52

\begin{tabular}{|c|c|c|c|c|c|c|}
\hline DLS expt & $\begin{array}{c}\text { concn } \\
\text { (mg/mL) }\end{array}$ & $\begin{array}{l}\text { base- } \\
\text { line }\end{array}$ & $\begin{array}{l}\text { SOS } \\
\text { error }^{a}\end{array}$ & $R_{\mathrm{H}}^{b}(\mathrm{~nm})$ & $\begin{array}{l}\text { peak } \\
\text { area }^{c} \\
(\%)\end{array}$ & $\begin{array}{l}\text { interpre- } \\
\text { tation }^{d}\end{array}$ \\
\hline 1. $20^{\circ} \mathrm{C}$ & 3.5 & 1.001 & 4.22 & $15.0(2.5)$ & 98.3 & $>2$ rings \\
\hline 2. heat to $50^{\circ} \mathrm{C}$ & 3.5 & 1.000 & 2.78 & $14.2(4.5)$ & 99.2 & $\sim 2$ rings \\
\hline 3. concd; $20^{\circ} \mathrm{C}$ & 4.9 & 1.002 & 2.03 & $4.3(0.5)$ & 3.4 & monomer \\
\hline \multirow[t]{3}{*}{ 4. concd; $20^{\circ} \mathrm{C}$} & 11.5 & 1.009 & 7.78 & $\begin{array}{r}18.7(2.3) \\
5.1(0.6)\end{array}$ & $\begin{array}{r}95.8 \\
4.2\end{array}$ & $\begin{array}{l}>2 \text { rings } \\
\text { mono/ } \\
\text { dimer }\end{array}$ \\
\hline & & & & $17.8(3.1)$ & 56.9 & $>2$ rings \\
\hline & & & & 36.1 & 36.6 & $\gg 2$ rings \\
\hline 5. heat to & 11.5 & 1.000 & 5.96 & 19.2( & 99.2 & $>2$ rings \\
\hline \multirow[t]{3}{*}{ 6. cool to $20^{\circ} \mathrm{C}$} & 115 & 1.010 & 8.24 & 5.9( & 9.7 & $\begin{array}{l}\text { mono/ } \\
\text { dimer }\end{array}$ \\
\hline & & & & 11.2 & 6.6 & $1-2$ rings \\
\hline & & & & 20.6 & 81.6 & $>2$ rings \\
\hline \multirow{2}{*}{$\begin{array}{l}\text { 7. sample from } \\
\text { line } 4 \text { diluted; } \\
20^{\circ} \mathrm{C}\end{array}$} & 3.5 & 1.001 & 11.3 & $3.8(0.2)$ & 0.6 & monomer \\
\hline & & & & 23.2 (11.6) & 98.1 & $>2$ rings \\
\hline \multirow[t]{2}{*}{ 8. heat to $50^{\circ} \mathrm{C}$} & 3.5 & 1.001 & 9.41 & $9.7(1.2)$ & 45.8 & 1 ring \\
\hline & & & & $17.0(1.0)$ & 49.8 & $>2$ rings \\
\hline \multirow[t]{3}{*}{ 9. $\operatorname{cool}$ to $20^{\circ} \mathrm{C}$} & 3.5 & 1.001 & 16.1 & $3.9(0.2)$ & 1.1 & monomer \\
\hline & & & & 11.9 (1.9) & 69.3 & $1-2$ rings \\
\hline & & & & $28.6(3.5)$ & 26.4 & $\gg 2$ rings \\
\hline \multirow{3}{*}{$\begin{array}{l}\text { 10. sample from } \\
\text { line } 3 \text { diluted; } \\
20^{\circ} \mathrm{C}\end{array}$} & 3.3 & 1.001 & 7.4 & $3.1(0.2)$ & 11.0 & monomer \\
\hline & & & & 16.8 & 84.0 & $>2$ rings \\
\hline & & & & 49.5 & 14.5 & $\gg 2$ rings \\
\hline 11. heat to $37^{\circ} \mathrm{C}$ & 3.3 & 1.000 & 7.9 & $19.8(10.9)$ & 99.5 & $>2$ rings \\
\hline $\begin{array}{l}\text { 12. sample from } \\
\text { line } 4 \text { diluted; } \\
20^{\circ} \mathrm{C}\end{array}$ & 2.3 & 1.001 & 50.9 & $8.75(6.0)$ & 79.7 & 1 ring \\
\hline 13. heat to $37^{\circ} \mathrm{C}$ & 2.3 & & 24.5 & & 71.9 & $1 \mathrm{ri}$ \\
\hline 14. heat to $50^{\circ} \mathrm{C}$ & 2.3 & 1.000 & 15.9 & $8.7(2.7)$ & 87.4 & 1 ring \\
\hline
\end{tabular}

${ }^{a} \mathrm{SOS}=$ sum of squares. ${ }^{b}$ Average $R_{\mathrm{H}}$ is given with the standard deviation given in parentheses. ${ }^{c}$ DynaLS results; the percent peak area for the solvent peaks was not reported. DLS measurements at 20 and $50{ }^{\circ} \mathrm{C}$ on solvent alone indicate that very small and very large components in the RAD52 measurements were due to the solvent and not the protein. Therefore, only the peaks attributable to RAD52 protein are reported $\left(R_{\mathrm{H}}>3.0 \mathrm{~nm}\right.$; see Figure 4$) . R_{\mathrm{H}}$ and percent peak area of the primary species in solution (greater than 10\%) are in bold. ${ }^{d}$ Interpretation is based on estimated $R_{\mathrm{H}}$ in Figure 4. It is not possible to tell exactly how many rings of RAD52 are in the aggregates $>14.1$ $\mathrm{nm}$ since the structure of the higher order complexes of RAD52 rings is unknown.

$\mathrm{mL}$ and then diluted (see Table 2 and Figure 3). The microsampler cell was held at 20,37 , or $50^{\circ} \mathrm{C}$, and samples were equilibrated for $30 \mathrm{~min}$ at the target temperature before DLS measurements began. The smallest $R_{\mathrm{H}}$ measured for RAD52 was $8.0-8.75 \mathrm{~nm}$ (Table 2, lines 12-14). This is close to the size expected for single rings measured from electron micrographs (Figure 4) (6-8). A monomer of RAD52 is expected to have an $R_{\mathrm{H}}$ value of $3.2 \mathrm{~nm}$, and complexes containing two rings are expected to have an $R_{\mathrm{H}}$ of $12.8-14.1 \mathrm{~nm}$. The $R_{\mathrm{H}}$ for aggregates of more than two rings would be greater than $14 \mathrm{~nm}$.

Using these estimates of particle sizes as a guide, four trends in the DLS data were noted. First, heating the protein samples from 20 to $50{ }^{\circ} \mathrm{C}$ caused the $R_{\mathrm{H}}$ to decrease in general, and frequently the baseline decreased to within the monomodal range. For example, heating a sample similar to that used for DSC measurements (Table 2, line 7, and Figure $3 \mathrm{E}$ ) caused the particles to shift from a single population with $R_{\mathrm{H}}$ of $23.2 \mathrm{~nm}$ to two populations with $R_{\mathrm{H}}$ of 9.7 and $17.0 \mathrm{~nm}$ (Table 2, line 8, and Figure 3F). Second, the size of the sample population was dependent on the protein concentration. For example, the $R_{\mathrm{H}}$ of the sample

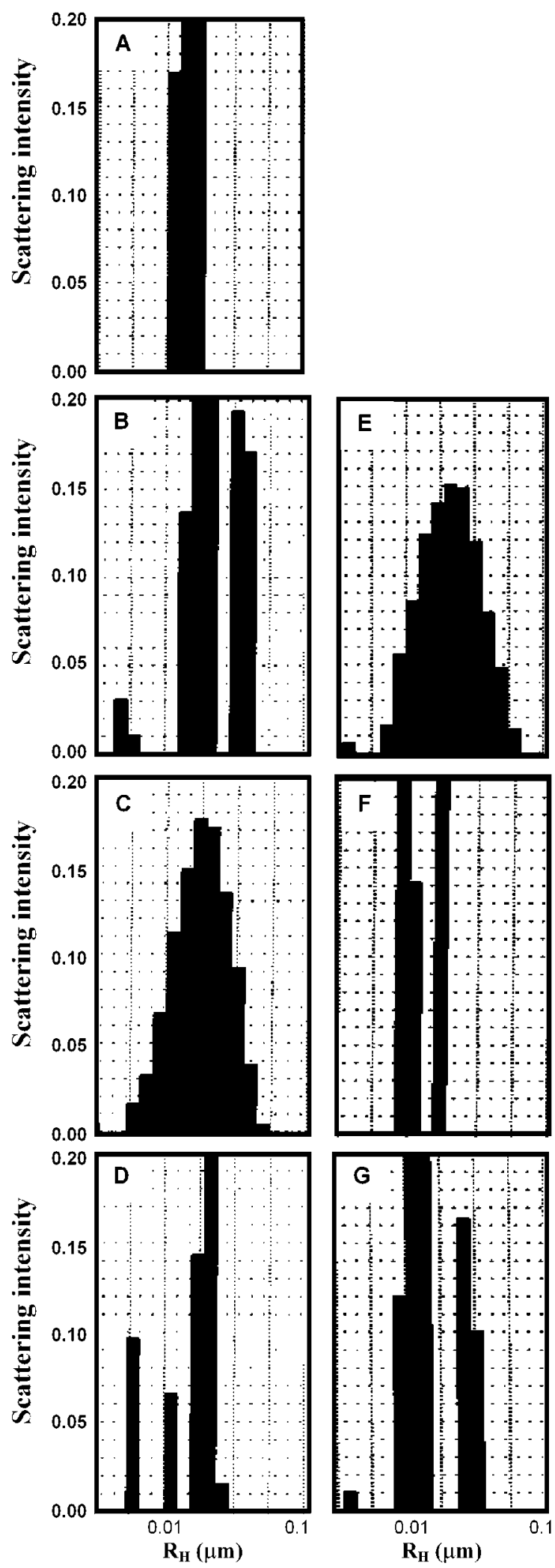

FIGURE 3: Effect of protein concentration and temperature on the $R_{\mathrm{H}}$ of wild-type RAD52. DLS data were analyzed using DynaLS software. The data correspond to the following lines in Table 2: (A) $3.5 \mathrm{mg} / \mathrm{mL}$ at $20{ }^{\circ} \mathrm{C}$ (line 1 ), (B) $11.5 \mathrm{mg} / \mathrm{mL}$ at $20^{\circ} \mathrm{C}$ (line 4), (C) $11.5 \mathrm{mg} / \mathrm{mL}$ at $50{ }^{\circ} \mathrm{C}$ (line 5), (D) $11.5 \mathrm{mg} / \mathrm{mL}$ cooled to $20{ }^{\circ} \mathrm{C}$ (line 6), (E) diluted to $3.5 \mathrm{mg} / \mathrm{mL}$ at $20{ }^{\circ} \mathrm{C}$ (line 7$),(\mathrm{F})$ diluted to $3.5 \mathrm{mg} / \mathrm{mL}$ at $50{ }^{\circ} \mathrm{C}$ (line 8), and $(\mathrm{G})$ diluted to $3.5 \mathrm{mg} /$ $\mathrm{mL}$ cooled to $20^{\circ} \mathrm{C}$ (line 9 ). Panels $\mathrm{E}-\mathrm{G}$ correspond to the sample used for DSC. 


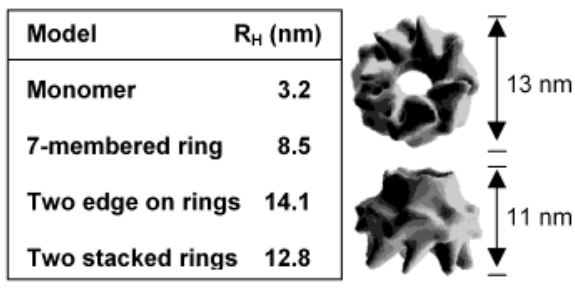

FiguRE 4: Estimated $R_{\mathrm{H}}$ for RAD52 models. The $R_{\mathrm{H}}$ for a monomer was calculated from a molecular mass of $47.0 \mathrm{kDa}$ with the molecular weight calculator included in the Dynamics 3.0 software. $R_{\mathrm{H}}$ for a seven-membered ring of RAD52 was estimated from the diagonal of the three-dimensional reconstruction on the basis of electron micrographs (9). Electron micrographs of RAD52 rings in the large, greater than $100 \mathrm{~nm}$ spherical aggregates appear to have an "edge-on" orientation (10). The three-dimensional reconstructions of RAD52 were adapted from Stasiak et al. (2000).

population increased from 15.0 to 18.7 to $36.1 \mathrm{~nm}$, when the concentration was increased from 3.5 to 4.9 to $11.5 \mathrm{mg} /$ $\mathrm{mL}$ (Table 2, lines 1, 3, and 4). Third, the modality of the sample population was dependent on the protein concentration. For example, the $11.5 \mathrm{mg} / \mathrm{mL}$ sample was multimodal at $20{ }^{\circ} \mathrm{C}$ (Table 2, line 4, and Figure 3B), and the $3.5 \mathrm{mg} /$ $\mathrm{mL}$ sample was not (Table 2, line 1, and Figure 3A). Fourth, the reversibility of the assembly of RAD52 rings into higher ordered complexes was dependent on protein concentration. The majority of the particles in the samples at $11.5 \mathrm{mg} / \mathrm{mL}$ remained greater than $17 \mathrm{~nm}$ throughout the heat cycle (Table 2, lines 4-6, and Figure 3B-D). But, the superaggregation of rings was only partially reversible at $3.5 \mathrm{mg} / \mathrm{mL}$ with only $26 \%$ of the sample returning to greater than $17 \mathrm{~nm}$ after being heated (Table 2, lines 7-9, and Figure 3E-G). It is noteworthy that for the DSC measurements made on samples at $3.5 \mathrm{mg} / \mathrm{mL}$ the assembly of RAD52 rings into higher ordered complexes is not completely reversible at this concentration.

Finally, this DLS analysis facilitated the interpretation of DSC transition A. Transition A could not be detected for samples that were first concentrated to $11.5 \mathrm{mg} / \mathrm{mL}$ and then diluted to $2.0 \mathrm{mg} / \mathrm{mL}$ (prepared as in line 12, Table 2). The $R_{\mathrm{H}}$ value of 8.75 indicates that at $2.0 \mathrm{mg} / \mathrm{mL}$ there are primarily single rings in solution and little or no higher ordered complexes (Figure 4). Transition A was detectable for samples that were diluted to $3.5 \mathrm{mg} / \mathrm{mL}$ (prepared as in line 7, Table 2, and Figure 3E). The $R_{\mathrm{H}}$ value of $23.2 \mathrm{~nm}$ indicates that at $3.5 \mathrm{mg} / \mathrm{mL}$ there are primarily higher order complexes of many rings in solution. Heating this sample to $50{ }^{\circ} \mathrm{C}$ caused the $R_{\mathrm{H}}$ to decrease and form two populations of 9.7-17.0 nm (Table 2, line 8, and Figure 3F). Therefore, these DLS data indicate that DSC transition A can be attributed to the disassociation of rings from higher ordered complexes.

We were interested to know if the higher ordered complexes of RAD52 rings were stable at physiological temperatures. Protein samples diluted to $3.3 \mathrm{mg} / \mathrm{mL}$ did not form particles less than $9 \mathrm{~nm}$ upon heating to $37^{\circ} \mathrm{C}$ (Table 2 , lines 10 and 11) although the samples became monomodal. Therefore, the upper level aggregation of RAD52 rings is stable at physiological temperatures in vitro.

Transition B of the RAD52(1-192) mutant was $47.6^{\circ} \mathrm{C}$, and attempts were made to measure the effect of temperature on the structure of RAD52(1-192) with DLS. Higher ordered assemblies of rings are not formed by RAD52(1-

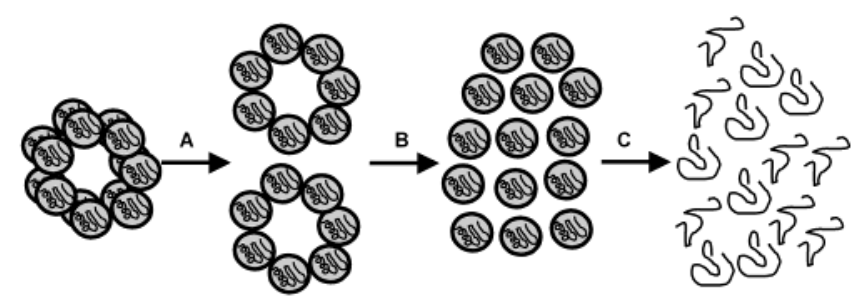

FIGURE 5: Hypothetical four- state model for the thermal denaturation of wild-type RAD52. Transitions A, B, and C correspond to those measured by DSC in Figure 2. There are three transitions in this model; transition $\mathrm{A}$ is attributed to the disruption of higher order assemblies of RAD52 rings, transition $\mathrm{B}$ to the disruption of rings to individual subunits, and transition $\mathrm{C}$ to complete unfolding. The individual subunits after transition $B$ are probably partially unfolded as well as disassociated from the rings.

192), and single rings have an $R_{\mathrm{H}}$ of $5.7 \mathrm{~nm}(\mathrm{SD}=1.2)$ (10). As samples of RAD52(1-192) were heated, the $R_{\mathrm{H}}$ appeared to increase, perhaps indicating partial unfolding (data not shown). DLS measurements at elevated temperatures with RAD52(1-192) were very problematic, and at $50{ }^{\circ} \mathrm{C}$ no measurements could be obtained, perhaps due to large changes in structure.

\section{CONCLUSIONS}

Our data indicate that the RAD52 rings and higher ordered complexes of rings used in DNA repair and DNA recombination are extremely stable structures. The structure of wild-type RAD52 is very stable, and its multiple levels of self-association appear to contribute to this stabilization. The extreme stability of the wild-type RAD52 and RAD52(1192) folds relative to RAD52(218-418) appears to be related to the assembly of multiple monomers into a ring. The enhanced stability of the wild-type RAD52 fold relative to RAD52(1-192) appears to be due in part to its ability to form higher order assemblies of rings.

A four-state hypothetical model has been developed to explain the thermal denaturation profile of wild-type RAD52 (Figure 5). There are three transitions in this model; transition $\mathrm{A}$ is attributed to the disruption of higher order assemblies of RAD52 rings, transition $\mathrm{B}$ to the disruption of rings to individual subunits, and transition $\mathrm{C}$ to complete unfolding. Individual rings of RAD52 appear to have an $R_{\mathrm{H}}$ on the order of $8.0-8.75 \mathrm{~nm}$ in solution (Table 2, lines 12-14). Higher order assemblies of rings are seen in the wild-type RAD52 DLS data as particles ranging from 15 to $50 \mathrm{~nm}$. Note that the measured $R_{\mathrm{H}}$ values are not integral values of individual rings due to the presence of equilibrium mixtures of single rings and complexes of rings in solution as indicated by the high standard deviations in the $R_{\mathrm{H}}$ measurements (Table 2) and the width of the DLS peaks (Figure 3). This equilibrium is dependent upon concentration. At concentrations of 3.5 $\mathrm{mg} / \mathrm{mL}$ or greater RAD52 appears to be primarily composed of assemblies of two or more rings with $R_{\mathrm{H}}$ values ranging from 15 to $36.1 \mathrm{~nm}$. Raising the temperature from 20 to 50 ${ }^{\circ} \mathrm{C}$ disrupts the higher order particles, pushing the equilibrium toward the $9 \mathrm{~nm}$ particles (Table 2, lines 5 and 8, and Figure $3 \mathrm{C}$ and $\mathrm{F}$ ). These data support our hypothetical model for transition A (Figure 5). Reliable DLS measurements varying temperature on RAD52(1-192) could not be made. Thermal expansion of the RAD52(1-192) rings was noted. The data indicate that a large structural transition occurs near transition 
$\mathrm{B}$, possibly the disassociation of individual subunits from the rings.

Only a handful of proteins have been measured with thermal stabilities on the order of RAD52. To our knowledge, the highest $T_{\mathrm{M}}$ for a protein reported in the literature to date is $125^{\circ} \mathrm{C}$ for ferredoxin from the hyperthermophile Thermotoga maritima (15). Other proteins such as onconase and mitochondrial manganese superoxide dismutase (MnSOD) are extremely stable with $T_{\mathrm{M}}$ 's approaching $90{ }^{\circ} \mathrm{C}(16,17)$. Both ferredoxin and onconase are monomeric, and by studying their protein crystal structures, their stabilities were attributed to the compactness of their tertiary structures and to extensive hydrogen bonding involving charged amino acid side chains. Mitochondrial MnSOD is a homotetramer, and its enhanced stability was partially attributed to its quaternary structure. The DSC profile of MnSOD has three thermal transitions (labeled A, B, and C), similar to those seen with RAD52. Transition A was attributed to subunit disassociation, transition $\mathrm{B}$ to loss of the active site manganese, and transition $\mathrm{C}$ to complete unfolding. A cavity forming point mutation in the tetrameric interface of MnSOD resulted in the lowering of transition $\mathrm{B}$ by $13.6^{\circ} \mathrm{C}$ and transition $\mathrm{C}$ by $16.5^{\circ} \mathrm{C}(17)$. These results on MnSOD are somewhat similar to the results on RAD52. We conclude from our data that both components of RAD52 self-association, ring formation and higher order complex formation, contribute to its extreme thermal stability. A precise understanding of the structural determinants of RAD52 stability awaits the solution of its crystal structure.

\section{ACKNOWLEDGMENT}

We thank Dr. Min Park for providing the expression plasmid for RAD52(1-192).

\section{REFERENCES}

1. Game, J., and Mortimer, R. K. (1974) Mutat. Res. 24, 281292.
2. Petes, T. D., Malone, R. E., and Symington, L. S. (1991) in The Molecular and Cellular Biology of the Yeast, Saccharomyces (Broach, J. R., Pringle, J. R., and Jones, E. W., Eds.) pp 407-522, Cold Spring Harbor Laboratory Press, Cold Spring Harbor, NY.

3. Shen, Z., Cloud, K. G., Chen, D. J., and Park, M. S. (1996) J. Biol. Chem. 271, 148-152.

4. Shen, Z., Peterson, S. R., Comeaux, J. C., Zastrow, D., Moyzis, R. K., Bradbury, E. M., and Chen, D. J. (1996) Mutat. Res. 364, 81-89.

5. Park, M. S., Ludwig, D. L., Stigger, E., and Lee, S. H. (1996) J. Biol. Chem. 271, 18996-19000.

6. Shinohara, A., Shinohara, M., Ohta, T., Matsuda, S., and Ogawa, T. (1998) Genes Cells 3, 145-156.

7. Van Dyck, E., Hajibagheri, N. M. A., Stasiak, A., and West, S. C. (1998) J. Mol. Biol. 284, 1027-1038.

8. Van Dyck, E., Stasiak, A. Z., Stasiak, A., and West, S. C. (1999) Nature 398, 728-731.

9. Stasiak, A. Z., Larquet, E., Stasiak, A., Muller, S., Engel, A., Dyck, E. V., West, S. C., and Egelman, E. H. (2000) Curr. Biol. 10, 337-340.

10. Ranatunga, W., Jackson, D., Lloyd, J. A., Forget, A. L., Knight, K. L., and Borgstahl, G. E. O. (2001) J. Biol. Chem. (in press).

11. Haynie, D. T., and Freire, E. (1994) Anal. Biochem. 216, $33-$ 41.

12. Ladbury, J., Wynn, R., Hellinga, H., and Sturtevant, J. (1993) Biochemistry 32, 7526-7530.

13. Ladbury, J., Kishore, N., Hellinga, H., Wynn, R., and Sturtevant, J. (1994) Biochemistry 33, 3688-3692.

14. Lu, Z., DiBlasio-Smith, E., Grant, K., Warne, N., LaVallie, E., Collins-Racie, L., Follettie, M., Williamson, M., and McCoy, J. (1996) J. Biol. Chem. 271, 5059-5065.

15. Pfeil, W., Gesierich, U., Kleemann, G. R., and Sterner, R. (1997) J. Mol. Biol. 272, 591-596.

16. Notomista, E., Catanzano, F., Graziano, G., Piaz, F. D., Barone, G., D'Alessio, G., and Donato, A. D. (2000) Biochemistry 39, 8711-8718.

17. Borgstahl, G. E. O., Parge, H. E., Hickey, M. J., Johnson, M. J., Boissinot, M., Hallewell, R. A., Lepock, J. R., Cabelli, D. E., and Tainer, J. A. (1996) Biochemistry 35, 4287-4297.

BI0155089 